DOI:

UDC 621.129 .12

D. Shmatko, PhD, Associate Professor, zombizon@yandex.ua

V. Averyanov, PhD, Associate Professor, averynov@ukr.net

A. Sasov, PhD, Associate Professor, sasov@ukr.net

O. Cherneta, PhD, Associate Professor, ocherneta@gmail.com

Dnipro State Technical University, Kamianske

\title{
MATHEMATICAL MODELING OF ROLLER WEAR
}

In the given work the method of noise-acoustic non-destructive control during carrying out of diagnostics of bearings of rolling of mats of wheels of cars is considered. The proposed nondestructive method of control provides an opportunity to check the efficiency of the selected lubricant, thereby increasing the life and performance of the bearings. A laboratory installation for the diagnosis of roller bearings has been created, which allows to obtain their acoustic parameters depending on the load of the bearing unit, the time of application and application of different types of lubricants in bearings. The mathematical model developed by the authors is aimed at determining the degree of wear of bearing shafts and allows them to predict their possible work life based on the received noiseacoustic parameters.

Keywords: bearing; non-destructive control; diagnostics; acoustic parameters; lubricants; laboratory setting.

В даній роботі розглядається метод шумо-акустичного неруйнівного контролю при проведенні діагностування підшипників кочення маточин коліс автомобілів. Запропонований неруйнівний метод контролю надає можливість перевірити ефективність обраного мастила, тим самим підвищити ресурс і працездатність підшипників. Створена лабораторна установка для діагностування підшипників кочення, яка дозволяс отримати їх акустичні параметри в залежності від навантаження підшипникового вузла, часу напраџювання $і$ застосування різних видів мастильних матеріалів у підшипниках. Розроблена авторами математична модель спрямована на визначення ступеню зношування підшипників кочення та дозволяє прогнозувати їх можливий ресурс роботи на підставі отриманих шумо-акустичних параметрів.

Ключові слова: підшипник; неруйнівний контроль; діагностика; акустичні параметри; мастильні матеріали; лабораторна установка.

\section{Formulation of the problem}

The resource of cars is determined, basically, by the rolling bearings resource. Defects in the manufacture and operation of bearings in different ways affect the signal of vibration and have different diagnostic features. This allows detecting defects at the stage of their occurrence and predict further development. The manufacturing defects include: deflection of the form in the fabrication of rolling bodies, unbalanced rings, eccentricity of the wraps, radial gaps; violation of roughness of rolling surface. The defects of installation include: defects of planting bearings in the nest; strong drag; wrong centering.

The main reasons for the release of the bearing are: failure of lubrication (40\%); violation of the montage (30\%); other causes (20\%); natural wear $(10 \%)[1,2]$.

The acoustic method of non-destructive control is based on the use of waves and elastic oscillations. When acoustic control is usually used oscillations with a frequency of $0,5 \ldots 25 \mathrm{MHz}$ (ultrasound) [3-5]. Therefore, most acoustic techniques are ultrasound, although there are known cases of use and oscillation of the sound frequency. Currently, four methods of ultrasound evaluation of the technical condition of rolling bearings are used in practice: the Peak-factor, the direct spectrum, the spectrographs and shock impulses.

\section{Analysis of recent research and publications}

Many scientists are involved in the diagnostics of parts and units of automobiles using nondestructive methods of control. Much attention is paid to the diagnosis of roller bearings. 
So in [6] the authors proposed a method for diagnosing bearings, which involves the use of deformation measurements obtained with the help of fiber optic sensors, which allows to estimate damage by measuring the size of small chips in the bearings of bearings. Using this method it is not possible to determine the degree of bearing of the bearing, but only to assess the degree of damage to its internal and external cartridges.

Work [7] is devoted to the method of evaluation of the quality of lubricants, namely the determination of contamination in the lubrication of rolling bearings using acoustic emission signals. The authors of the article argue that the signature of the contaminated lubricant is much stronger than the effect on conventional state indicators, such as RMS. However, a comprehensive evaluation of the application of one or another lubricant in the roller bearing does not provide for the proposed method.

Proposed in [8], the methodology for the diagnosis of rolling bearings uses packet wavelet transformation, tracking the order and the approach to modeling the features for generating the diagnostic metric as a measure of difference. The disadvantages of this method of diagnostics include its great complexity (it is necessary to carry out the assessment of the distribution of the probability of the diagnostic metric, which is statistically determined in the relevant conditions of use), as well as some inaccuracy in the evaluation of bearing applications with or without lubricants.

The proposed method for the diagnosis of bearings [9] involves obtaining parameters using the method of vibration. This method of variable structure was used to improve the reliability of the malfunctioning while simultaneously reducing the uncertainty in the feedback linearization observer. The main disadvantage of diagnosing with the linearization method is that the equivalence of the initial nonlinear system and its linear approximation is preserved only for certain processes, and if the system moves from one mode to another, it is necessary to change its linearized model, that is, it makes it impossible to take into account the change in the load on bearing unit.

The method of diagnosing roller bearings in labor [10] involves identifying and eliminating defects in bearings at the stage of harvesting them in the bearings of the assembly. The authors investigate the geometry and vibration signals generated by the acting bearings. The proposed method does not make it possible to evaluate the bearing life after a certain period of working time, as well as evaluate the efficiency of the lubricant used in it.

\section{Formation of the research goal}

The purpose of the work is to develop a methodology for conducting studies of the performance of rolling bearings by the method of acoustic non-destructive testing and to obtain the dependence of the acoustic performance of the bearings on their performance, as well as the use of lubricants in them. Development of a mathematical model that predicts the rolling bearing actuation, depending on its acoustic parameters.

\section{Presenting main material}

Experimental studies were carried out on a laboratory installation (Fig. 1) for the diagnosis of roller bearings [11], using a sound-acoustic method using the software GoldWawe and Spectrogram. For research, the bearings of the front hub of the Mercedes Vito are selected.

Experiment on research of noise-acoustic indices of rolling bearings was carried out in several stages. The first stage was carried out as follows: the bearing of the wheel hub was lubricated with lubricant number 158, and installed on a laboratory installation (Fig. 1), that is, the case with a bearing was installed with a tension on the shaft and connected to the electric motor; the system of the levers changed the load on the shaft on which the post - The bearings are rolling, thus changing the load on the bearing itself.

With acoustic sensors and computer technology, audio files were recorded with the corresponding software; after switching off the plant, it was partially disassembled to replace the bearings with another lubricant. Next, the next launch of the installation with bearings was used in which the lubricant LITOL-24 and CIATIM-201 was used and the audio files were recorded. The load shift on the bearing also occurred with the use of counter-loads.

Several cycles of filing the bearings with different lubricants and different loadings on the bearing unit were carried out, and then analysis of these files was performed using GoldWave and Spectrogram programs. 

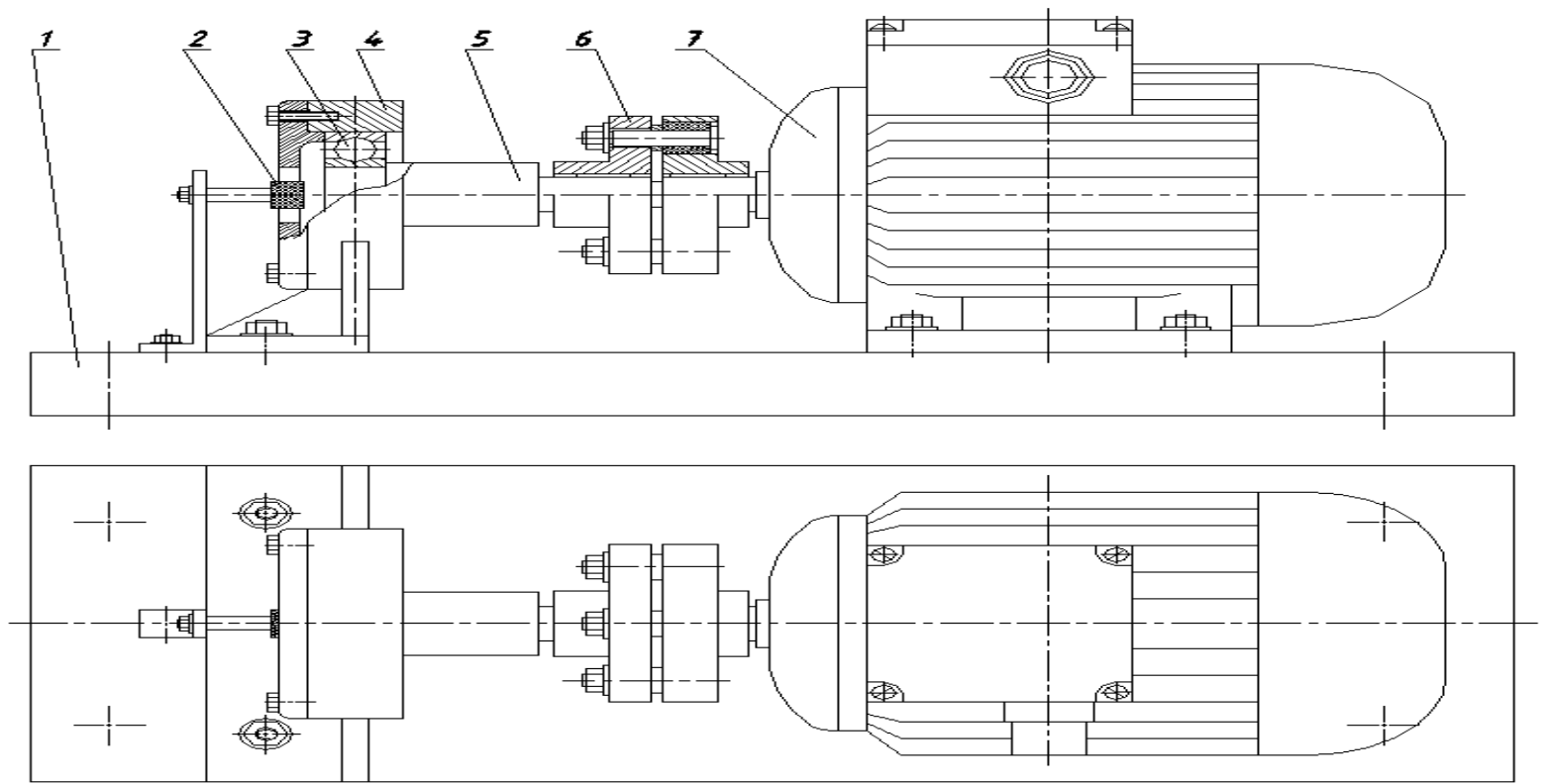

Fig. 1. Installation for the diagnosis of roller bearings: 1 - frame; 2 - noise sensor; 3 - rolling bearing; 4 - bearing support; 5 - intermediate shaft; 6 - coupling; 7 - electric motor

The obtained data (spectrographs, diagrams and noise indicators) allow visually seeing and analyzing the wear condition of the bearing and the development of the defect in it, as well as the influence of the lubricant on the behavior of the noise-acoustic indicators.

An analysis of audio files (Fig. 2) made it possible to see how the behavior of the vibration acoustic indices of the bearing changes with the use of different lubricants.

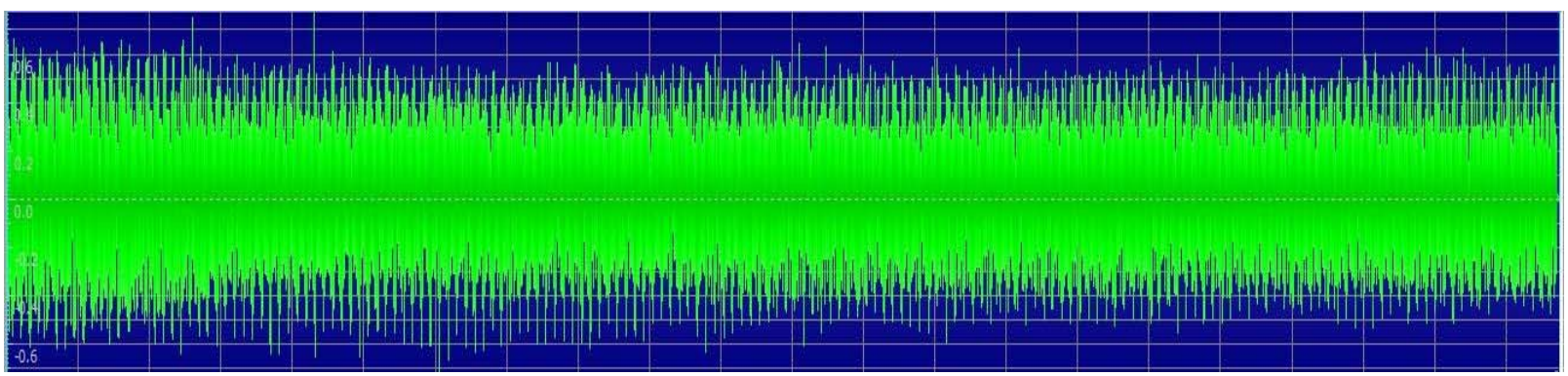

Fig. 2. Diagrams of noise-acoustic indicators for bearings with the use of different lubricants

Diagrams allow you to clearly see the development of the defect and the overall picture of the state of the experimental under-spike and the dependence of the condition on the lubricant. The white color in the diagram shows the initial state of the test bearing, and the black is the limiting state.

The experiment used an electret microphone, microphone with the principle of action similar to the micro-phonons of the condenser type, which uses as a stationary plate of the condenser and the source of the post-voltage voltage plate from the electret.

Tabl. 1 provides data on the magnitude of the noise band that was recorded during each cycle of the experiment with different lubricants. 
Table 1. Results of noise level measurement

\begin{tabular}{|c|c|c|c|c|c|c|c|c|c|}
\hline \multicolumn{2}{|c|}{ Working hours, hours } & 100 & 200 & 300 & 400 & 500 & 600 & 800 & 1000 \\
\hline \multicolumn{2}{|c|}{$\begin{array}{l}\text { Number of revolutions of a } \\
\text { bearing, } 10^{6} \mathrm{rev}\end{array}$} & 6 & 12 & 18 & 24 & 30 & 36 & 48 & 60 \\
\hline \multirow{9}{*}{ 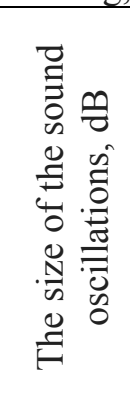 } & \multirow{3}{*}{ Lubricant№158 } & 47.2 & 47.2 & 48.1 & 50.5 & 56.4 & 61.3 & 70.4 & 75.1 \\
\hline & & 47.5 & 47.3 & 48.3 & 50.4 & 56.6 & 61.7 & 70.5 & 75.2 \\
\hline & & 47.3 & 47.5 & 48.6 & 50.9 & 56.4 & 61.2 & 70.3 & 75.5 \\
\hline & \multirow{3}{*}{ LITOL-24 } & 45.3 & 46.4 & 49.4 & 55.3 & 61.1 & 69.6 & 77.7 & 78.3 \\
\hline & & 45.5 & 46.1 & 49.7 & 55.7 & 61.2 & 69.2 & 77.4 & 78.6 \\
\hline & & 45.4 & 46.3 & 49.5 & 55.8 & 61.5 & 69.4 & 77.9 & 78.4 \\
\hline & \multirow{3}{*}{ CIATIM-201 } & 42.3 & 50.4 & 56.2 & 64.6 & 68.3 & 74.3 & 78.4 & 80.3 \\
\hline & & 42.5 & 49.5 & 56.7 & 64.5 & 68.6 & 74.4 & 78.8 & 80.4 \\
\hline & & 42.6 & 49.8 & 56.3 & 64.2 & 68.4 & 74.5 & 78.4 & 80.5 \\
\hline
\end{tabular}

Fig. 3 shows the dependence of sound vibrations magnitude on the development ofbearings and mastic materials.

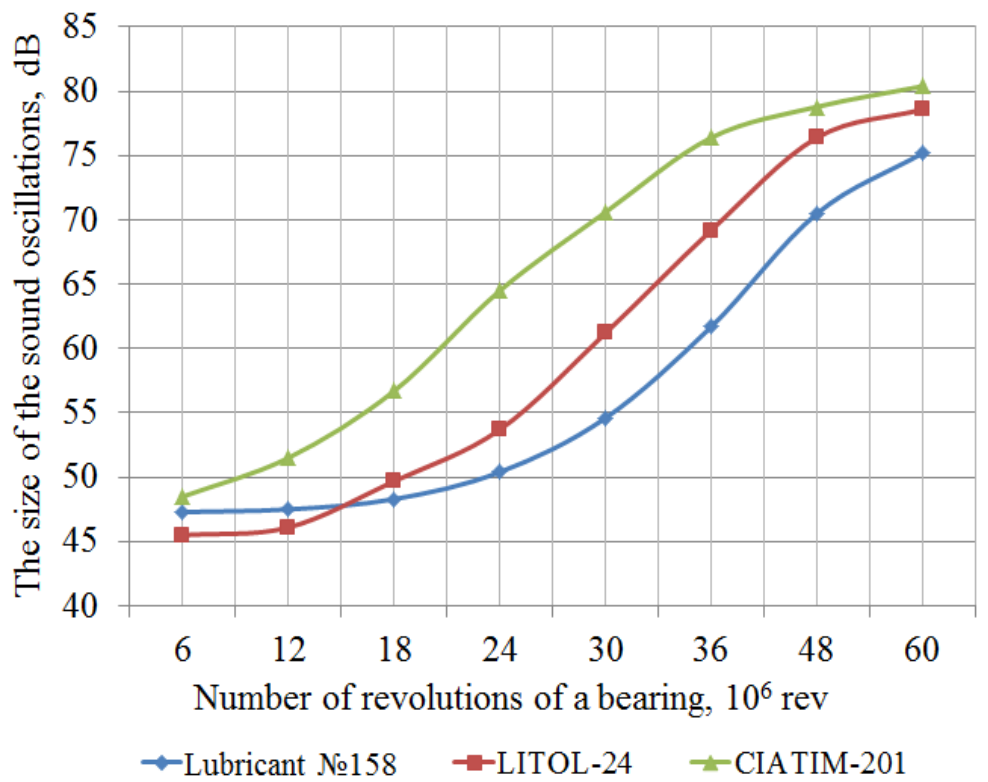

Fig. 3. The dependence of sound vibrations magnitude on the development for bearings and lubricants

In the second stage, the dependence of the radial beating of the bearings of the hub of the wheel on their overall performance was measured and the corresponding value of sound oscillations was measured. To determine the indications of radial beating of rolling bearings, a clock-type indicator mounted on a magnetic rack was used. The values of radial beating of bearings from their total output are given in Tabl. 2 . 
Table 2. Radial beating of bearings from their overall work

\begin{tabular}{|l|c|c|c|c|c|c|c|c|}
\hline $\begin{array}{c}\text { Number of revolutions of a } \\
\text { bearing, } 10^{6} \text { rev }\end{array}$ & 6 & 12 & 18 & 24 & 30 & 36 & 48 & 60 \\
\hline $\begin{array}{l}\text { Radial beating of bearings, } \\
\text { Mm }\end{array}$ & 9.5 & 11.2 & 12.1 & 15.4 & 18.2 & 25.4 & 32.6 & 41.3 \\
\hline $\begin{array}{c}\text { The size of the sound oscilla- } \\
\text { tions, dB }\end{array}$ & 42.3 & 49.4 & 56.2 & 64.6 & 68.3 & 74.3 & 78.4 & 85.3 \\
\hline
\end{tabular}

Fig. 4 shows the dependence of the radial beat of bearings on the value of sound vibrations. For the bearing of the hub of the wheel, which was investigated, the permissible values of radial beats were set, which make up for the lower limit of $10 \mathrm{~mm}$, and for the upper one $-35 \mathrm{~mm}$. Depending on the value of the sound vibrations, we determine the degree of bearing operation and its possible work life.

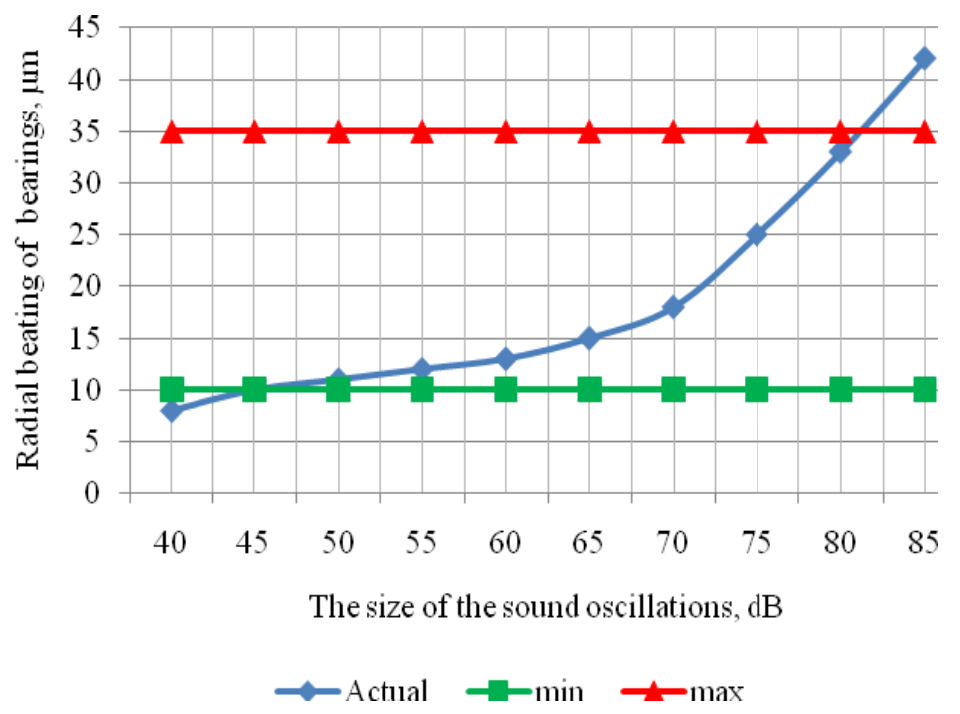

Fig. 4. Dependence of radial beating bearings on the value of sound oscillations

In the third stage a mathematical model was obtained for determining the dependence of acoustic parameters of bearings on their wear. This model takes into account the following parameters: the number of revolutions of the bearing; Load bearing perceived by the bearer; type of grease (number of penetration). Levels of variation above the above parameters are presented in Tabl. 3 .

Table 3. Levels of factors variation

\begin{tabular}{|l|c|c|c|c|c|c|}
\hline \multicolumn{1}{|c|}{ Factors } & $\begin{array}{c}\text { Marking } \\
\text { factors }\end{array}$ & $x_{i}^{*}=-1.68$ & $x_{i}=-1$ & $x_{i}=0$ & $x_{i}=1$ & $x_{i}^{*}=1.68$ \\
\hline $\begin{array}{l}\text { Number of revolutions of a bear- } \\
\text { ing } N, 10^{6} \text { rev }\end{array}$ & $x_{1}$ & 5 & 15 & 30 & 45 & 55 \\
\hline $\begin{array}{l}\text { Load bearing perceived by the } \\
\text { bearer } G, 10^{3} \mathrm{H}\end{array}$ & $x_{2}$ & 4.5 & 5.5 & 7 & 8.5 & 9.5 \\
\hline $\begin{array}{l}\text { Number of lubrication penetra- } \\
\text { tion } c, \mathrm{~mm}^{-1}\end{array}$ & $x_{3}$ & 235 & 250 & 270 & 290 & 305 \\
\hline
\end{tabular}


Encoding of factors by means of transformation:

$$
x_{j}=\frac{\tilde{x}_{j}-\tilde{x}_{j 0}}{I_{j}}
$$

where $x_{j}$ - coded value of the factor; $\tilde{x}_{j}$ - the natural value of the factor; $\tilde{x}_{j 0}$ - the natural value of the main level; $I_{j}$ - variation interval; $j$ - factor number.

We show the matrix of the plan calculated according to the formula and the corresponding results of the experiment obtained (Tabl. 4).

Table 4. The matrix of planning and research results

\begin{tabular}{|c|c|c|c|c|c|c|c|c|c|c|c|c|c|}
\hline 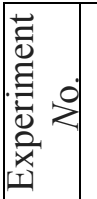 & $x_{0}$ & $x_{1}$ & $x_{2}$ & $x_{3}$ & $x_{1} x_{2}$ & $x_{1} x_{3}$ & $x_{2} x_{3}$ & $x_{1}^{2}$ & $x_{2}^{2}$ & $x^{2}{ }_{3}$ & $y$ & $y_{p}$ & 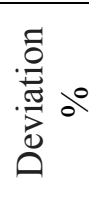 \\
\hline \begin{tabular}{l|l}
1 \\
\end{tabular} & 1 & 1 & 1 & 1 & 1 & 1 & 1 & 1 & 1 & 1 & 78.2 & 77.3 & 1.15 \\
\hline 2 & 1 & 1 & 1 & -1 & 1 & -1 & -1 & 1 & 1 & 1 & 76.6 & 75.3 & 1.7 \\
\hline 3 & 1 & 1 & -1 & 1 & -1 & 1 & -1 & 1 & 1 & 1 & 65.8 & 66.5 & -1.1 \\
\hline 4 & 1 & 1 & -1 & -1 & -1 & -1 & 1 & 1 & 1 & 1 & 67.3 & 66.5 & 1.19 \\
\hline 5 & 1 & -1 & 1 & 1 & -1 & -1 & 1 & 1 & 1 & 1 & 52.4 & 53.3 & -1.7 \\
\hline 6 & 1 & -1 & 1 & -1 & -1 & 1 & -1 & 1 & 1 & 1 & 53.8 & 53.3 & 0.93 \\
\hline 7 & 1 & -1 & -1 & 1 & 1 & -1 & -1 & 1 & 1 & 1 & 45.1 & 45.5 & -0.9 \\
\hline 8 & 1 & -1 & -1 & -1 & 1 & 1 & 1 & 1 & 1 & 1 & 46.4 & 45,5 & 1,94 \\
\hline 9 & 1 & 1.68 & 0 & 0 & 0 & 0 & 0 & 2.83 & 0 & 0 & 80.0 & 81.1 & -1.4 \\
\hline 10 & 1 & -1.68 & 0 & 0 & 0 & 0 & 0 & 2.83 & 0 & 0 & 45.2 & 44.5 & 1.55 \\
\hline 11 & 1 & 0 & 1.68 & 0 & 0 & 0 & 0 & 0 & 2.83 & 0 & 64.6 & 65.6 & -1.5 \\
\hline 12 & 1 & 0 & -1.68 & 0 & 0 & 0 & 0 & 0 & 2.83 & 0 & 52.7 & 51.6 & 2.09 \\
\hline 13 & 1 & 0 & 0 & 1.68 & 0 & 0 & 0 & 0 & 0 & 2.83 & 57.2 & 58.4 & -2.1 \\
\hline 14 & 1 & 0 & 0 & -1.68 & 0 & 0 & 0 & 0 & 0 & 2.83 & 58.8 & 58.4 & 0.68 \\
\hline 15 & 1 & 0 & 0 & 0 & 0 & 0 & 0 & 0 & 0 & 0 & 57.6 & 58.4 & -1.4 \\
\hline 16 & 1 & 0 & 0 & 0 & 0 & 0 & 0 & 0 & 0 & 0 & 5.1 & 58.4 & -2.3 \\
\hline 17 & 1 & 0 & 0 & 0 & 0 & 0 & 0 & 0 & 0 & 0 & 58.8 & 58.4 & 0.68 \\
\hline 18 & 1 & 0 & 0 & 0 & 0 & 0 & 0 & 0 & 0 & 0 & 59.3 & 58.4 & 1.52 \\
\hline 19 & 1 & 0 & 0 & 0 & 0 & 0 & 0 & 0 & 0 & 0 & 59.1 & 58.4 & 1.18 \\
\hline 20 & 1 & 0 & 0 & 0 & 0 & 0 & 0 & 0 & 0 & 0 & 59.6 & 58.4 & 2.01 \\
\hline
\end{tabular}

In this case, the mathematical model for a complete four factor experiment with the interaction of the mode has the form:

$$
y_{p}=b_{0}+b_{1} x_{1}+b_{2} x_{2}+b_{3} x_{3}+b_{12} x_{1} x_{2}+b_{13} x_{1} x_{3}+b_{23} x_{2} x_{3}+b_{11} x_{1}^{2}+b_{22} x_{2}^{2}+b_{33} x_{3}^{2} .
$$

The coefficients of the model are calculated by the formula:

$$
b_{j}=\frac{\sum_{i=1}^{N} x_{j i} \cdot y_{i}}{N},
$$

where $j=0,1,2, \ldots, k ; N$ - number of performed experiments $(N=20)$.

The coefficients of the model (2), which are calculated by the formula (3), make up:

$$
b_{0}=58.5 ; b_{1}=10.9 ; b_{2}=4.1 ; b_{3}=-0.83 ; b_{12}=1.5 ; b_{13}=0.25 ; b_{23}=0.75 ;
$$$$
b_{11}=1.55 ; b_{22}=0.14 ; b_{33}=-0.4 \text {. }
$$ 
The dispersion $S_{y}^{2}$ of reproducibility is determined by the results of research in the center of the plan. Dispersions that characterize the errors in determining the coefficients of the regression equation according to [12] for $k=4$ are:

$$
S^{2}\left\{b_{0}\right\}=0.5833 ; S^{2}\left\{b_{i}\right\}=0.2563 ; S^{2}\left\{b_{i l}\right\}=0.1375 ; S^{2}\left\{b_{i i}\right\}=0.0433 .
$$

When checking the coefficients by the criterion of the Investigator (with a $5 \%$ level of significance and a degree of free-body $f=4$ ) found that all the coefficients are significant and exceptionally to the model (2).

Substituting the found coefficients into equation (2), we obtain the following relation:

$$
\begin{aligned}
& y=58.5+10.9 \cdot \widetilde{x}_{1}+4.1 \cdot \widetilde{x}_{2}-0.83 \cdot \widetilde{x}_{3}+1.5 \cdot \widetilde{x}_{1} \cdot \widetilde{x}_{2}+0.25 \cdot \widetilde{x}_{1} \cdot \widetilde{x}_{3}+0.75 \cdot \widetilde{x}_{2} \cdot \widetilde{x}_{3}+ \\
& +1.55 \cdot \widetilde{x}_{1}^{2}+0.14 \cdot \widetilde{x}_{2}^{2}-0.4 \cdot \widetilde{x}_{3}^{2} .
\end{aligned}
$$

The verification of the hypothesis of the adequacy of the model (4) according to Fisher's criterion at the $5 \%$ level of significance and the degrees of freedom of dispersion of adequacy $f_{a d}=N-k-\left(n_{0}-1\right)=20-4-(6-1)=11$ and dispersion of reproducibility $f_{y}=n_{0}-1=6-1=5$ showed that the obtained models are adequate, since the calculated value of the criterion is less tabular $F_{\text {cal }}=1,54<F_{T}(0,05 ; 11 ; 5)=3.2[13]$.

In the equation (4), the variables $\widetilde{x}_{1}, \widetilde{x}_{2}, \widetilde{x}_{3}$ are coded values:

$$
\begin{aligned}
& \tilde{x}_{1}=\frac{N-30}{15}=0.067 \cdot N-2 ; \\
& \tilde{x}_{2}=\frac{G-7}{1,5}=0.67 \cdot G-4,67 ; \\
& \tilde{x}_{3}=\frac{\rho-270}{20}=0.05 \cdot \rho-13,5 .
\end{aligned}
$$

where $N$ - number of revolutions of a bearing, $10^{6} \mathrm{rev}$; $G$ - load bearing perceived by the bearer, $10^{3} \mathrm{H} ; c$ - number of lubrication penetration, $\mathrm{mm}^{-1}$.

For ease of computation, we convert the mathematical model (4) to a natural value:

$$
\begin{aligned}
& \partial B=33.15-0.381 \cdot N-6.92 \cdot G+0.3 \cdot \rho+0.067 \cdot N \cdot G+0.00084 \cdot N \cdot \rho+0.025 \cdot G \cdot \rho+ \\
& +0.007 \cdot N^{2}+0.063 \cdot G^{2}-0.001 \cdot \rho^{2} .
\end{aligned}
$$

\section{Conclusions}

On the basis of the conducted experiment and the analysis of the data obtained, it can be concluded that the method of non-destructive noise-acoustic control of roller bearings with the use of various lubricants is used to obtain the most reliable data on the degree of wear of rolling bearings, their operation and to prevent the destruction of the entire site as a whole.

The considered noise-acoustic method allows us to develop recommendations for the application of certain types of lubricants in roller bearings.

The developed mathematical model allows, based on the acoustic parameters of the bearings, which were obtained during experimental studies, to determine the degree of wear and to predict the potential life of the bearing roller.

\section{References}

[1] Korobochka, O., Skornyakov, E., Sasov, O. (2007) Osnovy rozrakhunkiv, proektuvannia i ekspluatatsii tekhnichnoho obladnanniadlia avtomobilnoho transportu [Fundamentals of calculation, design and operation of technical equipment for motor transport]. Dneprodzerzhinsk: DSTU [in Ukrainian].

[2] Kanevsky, I., Sampikova, I. (2007) Nerazrushayuschie metody i kontrolya [Nondestructive methods of control]. Vladivostok: DVSTU [in Russian].

[3] Klyuev, V., Sosnin, F., Kovalyov, A. (2003) Nerazrushayuschiy kontrol i diagnostik [NonDestructive Testing and Diagnostics]. Moscow: Mashinostroenie [in Russian]. 
[4] Martyinovskiy, V. (2002) Ispolzovanie spectra ogibayuschey visokochastotnoy vibratsii dlya diagnostiki podshipnikov kacheniya [Using the envelope spectrum of high-frequency vibration to diagnose rolling bearings]. Tehnicheskaya diagnostika i nerazrushayuschiy kontrol - Technical diagnostics and non-destructive testing, 3, 17-22 [in Russian].

[5] Shipulin, M., Li, R., Butan, A. (2010) Vosstanovlenie polimernoy kompozitsiey i nerazrushayuschiy kontrol podshipnikov kacheniya selskohozyaystvennoy tehniki [The restoration of the polymer composition and non-destructive testing of rolling bearings of agricultural machinery]. Vestnik MichGAU - Herald MichGAU, 1,181-185.

[6] Alian, H., Konforty, S., Ben-Simon, U., Klein, R., Tur, M., Bortman, J. (2019) Bearing fault detection and fault size estimation using fiber-optic sensors. Mechanical Systems and Signal Processing, 120(1), 392-407.

[7] Martin-del-Campo, S., Schnabel, S., Sandin, F., Marklund, P. (2019) Detection of particle contaminants in rolling element bearings with un supervised acoustic emission feature learning. Tribology International, 63(1), 30-38.

[8] Schmidt, S., Heyns, P., Gryllias, K. (2019) A discrepancy analysis methodology for rolling element bearing diagnostics under variable speed conditions. Mechanical Systems and Signal Processing, 116, 40-61.

[9] Piltan, F., Kim, J. (2018) Bearing fault diagnosis using an extended variable structure feedback linearization observer. Sensors (Switzerland), 18(12), 43-59.

[10] Jakubek, B., Jakubowicz, M., Smuiek, W. (2018) Comparison of rolling bearings' diagnosing methods - Procedures of damage introduction. Vibrations in Physical Systems, 29, 11-19.

[11] 11.Shmatko, D., Averyanov, V., Slota, I. (1017) Otrymannia shumo-diahnostychnykh parametriv pidshypnykiv kochennia $\mathrm{v}$ zalezhnosti vid zastosuvannia mastylnykh materialiv v laboratornykh umovakh [Obtaining noise-diagnostic parameters of rolling bearings, depending on the use of lubricants in the laboratory]. Zbirnyk naukovykh prats Lutskoho natsionalnoho tekhnichnoho universytetu - Collection of scientific papers of Lutsk National Technical University, 10, 217 221 [in Ukrainian].

[12] Shklyar, V. (2010). Planirovanie eksperimenta i obrabotka rezultatov [Experiment planning and results processing]. Tomsk: TPU, [in Russian].

[13] Suhov, A. (1982) Matematicheskaya obrabotka rezultatov izmereniy [Mathematical processing of measurement results]. Moscow: MISI [in Russian].

\section{МАТЕМАТИЧНЕ МОДЕЛЮВАННЯ ЗНОШУВАННЯ ПІДШИПНИКІВ КОЧЕННЯ \\ Шматко Д.3., Авер'янов В.С., Сасов О.О., Чернета О.Г.}

\section{Реферат}

Ресурс автомобілів визначається, в основному, ресурсом підшипників кочення. Дефекти виготовлення і експлуатації підшипників по різному впливають на сигнал вібрації і мають різні діагностичні ознаки. Це дозволяє виявити дефекти на етапі їх виникнення та прогнозувати подальший розвиток. До дефектів виготовлення відносяться: відхилення форми при виготовленні тіл кочення, неврівноваженість кілець, ексцентриситет обойми, радіальні зазори; порушення шорсткості поверхні кочення. До дефектів монтажу відносяться: дефекти посадки підшипників у гнізда; сильне затягування; неправильне центрування.

Акустичний метод неруйнівного контролю заснований на використанні хвиль і пружних коливань. При акустичному контролі зазвичай використовують коливання з частотою 0,5...25 МГц (ультразвукові). Тому більшість акустичних методів $€$ ультразвуковими, хоча відомі випадки використання і коливань звукової частоти. У даний час в практиці використову- 
ються чотири методи ультразвукової оцінки технічного стану підшипників кочення: Пікчинника, прямого спектру, спектру огинаючих і ударних імпульсів.

Метою роботи являється розробка методики проведення досліджень працездатності підшипників кочення методом акустичного неруйнівного контролю та отримання залежностей акустичних показників роботи підшипників від їх напрацювання, а також застосування в них мастильних матеріалів. Розробка математичної моделі, яка передбачає оцінювання спрацювання підшипника кочення в залежності від його акустичних параметрів.

На основі проведеного експерименту та аналізу отриманих даних, можна зробити висновок, що застосований метод неруйнівного шумо-акустичного контролю підшипників кочення з застосуванням різних мастильних матеріалів, дозволяє отримати найбільш достовірні данні про ступінь зношення підшипників кочення, їх спрацювання та попередити руйнування всього вузла в цілому.

Розглянутий шумо-акустичний метод дозволяє розробити рекомендації по застосуванню тих чи інших видів мастильних матеріалів у підшипниках кочення.

Розроблена математична модель дозволяє на підставі акустичних параметрів підшипників, які були отримані при проведені експериментальних досліджень, визначити ступінь зношування та прогнозувати можливий ресурс роботи підшипника кочення.

\section{Література}

1 Коробочка О. М., Скорняков Е. С., Сасов О. О. Основи розрахунків, проектування і експлуатації технічного обладнання для автомобільного транспорту : навч. посіб. Дніпродзержинськ: ДДТУ, 2007. 226 с.

2 Каневский И. Н., Сампікова О. Н. Неразрушающие методы контроля : учеб. пооб. Владивосток: ДВГТУ, 2007. 243 с.

3 Клюев В. В., Соснин Ф. Р., Ковалёв А. В. Неразрушающий контроль и диагностика: Справочник. Москва: Машиностроение, 2003. 656 с.

4 Мартыновский В. А. Использование спектра огибающей высокочастотной вибрации для диагностики подшипников качения. Техническая диагностика и неразрушающий контроль. 2002. №3. С. 17-22.

5 Шипулин М. А., Ли Р. И., Бутан А. В. Восстановление полимерной композицией и неразрушающий контроль подшипников каченя сельскохозяйственной техники. Вестник МичГАУ. 2010. №1. C. 181-185.

6 Alian H., Konforty S., Ben-Simon U., Klein R., Tur M., Bortman J. Bearing fault detection and fault size estimation using fiber-optic sensors. Mechanical Systems and Signal Processing. 2019. Vol. 120(1). P. 392-407.

7 Martin-del-Campo S., Schnabel S., Sandin F., Marklund P. Detection of particle contaminants in rolling element bearings with un supervised acoustic emission feature learning. Tribology International. 2019. Vol. 63(1). P. 30-38.

8 Schmidt S., Heyns P., Gryllias K. A discrepancy analysis methodology for rolling element bearing diagnostics under variable speed conditions. Mechanical Systems and Signal Processing. 2019. Vol. 116. P. 40-61.

9 Piltan F., Kim J. Bearing fault diagnosis using an extended variable structure feedback linearization observer. Sensors (Switzerland). 2018. Vol. 18(12). P. 43-59.

10 Jakubek B., Jakubowicz M., Smuiek W. Comparison of rolling bearings' diagnosing methods Procedures of damage introduction. Vibrations in Physical Systems. 2018. Vol. 29. P. 11-19.

11 Шматко Д. 3., Авер,янов В. С., Слота I. О. Отримання шумо-діагностичних параметрів підшипників кочення в залежності від застосування мастильних матеріалів в лабораторних умовах. Збірник наукових праиьь Луиького наџіонального технічного університету. 2017. Вип.10. С. 217-221

12 Шкляр В. С. Планирование эксперимента и обработка результатов. Томск: ТПУ, 2010. 247 с.

13 Сухов А. Н. Математическая обработка результатов измерений : учеб. пособ. Москва: МИСИ, 1982.89 c. 